\title{
Effect of S Content on the MnS Precipitation in Steel with Oxide Nuclei
}

\author{
Masamitsu WAKOH, Takashi SAWAI') and Shozo MIZOGUCHI') \\ Formerly Process Research Technology Laboratories, Nippon Steel Corporation. Now at Oita R \& D Laboratory, Nippon \\ Steel Corporation, Oaza, Nishinosu, Oita, Oita-ken, 870 Japan. $\quad 1$ 1) Formerly Process Research Technology Laboratories, \\ Nippon Steel Corporation. Now at Kimitsu R \& D Laboratory, Nippon Steel Corporation, Kimitsu, Kimitsu, Chiba-ken, 299-11 \\ Japan. $\quad 2$ ) Formerly Process Research Technology Laboratories, Nippon Steel Corporation. Now at Yawata R \& D \\ Laboratory, Nippon Steel Corporation, Tobihata, Tobata-ku, Kitakyushu, Fukuoka-ken, 804 Japan.
}

(Received on January 8, 1996; accepted in final form on March 4, 1996)

\begin{abstract}
Manganese sulphide formation experiments were carried out by deoxidizing with various elements and by changing $S$ content to clarify the effect of $S$ content on the MnS precipitation with various kinds of oxide nuclei. The behavior of $\mathrm{MnS}$ precipitation on oxide particles in the steel with 1 mass $\%$ of $\mathrm{Mn}$ was characterized according to $S$ content. When S content was below $100 \mathrm{ppm}$, a lot of MnS precipitated only on some kinds of oxide. It is effective to use an oxide having high sulphide capacity and low melting temperature for uniform dispersion of fine $\mathrm{MnS}$. On the other hand, when S was above $100 \mathrm{ppm}$, almost all the oxides worked as the precipitation sites of $\mathrm{MnS}$. In that case, for the MnS dispersion, it is better to select the oxide which tends to disperse finely itself in steel. The average diameter of $\mathrm{MnS}$, calculated by using a mathematical model considering the oxide nuclei with changing the precipitation ratio according to $S$ content and to the kind of oxides, agrees well with the experimental data.
\end{abstract}

KEY WORDS: low carbon steel; inclusions; nucleus; oxide; precipitation; solidification; manganese sulphide; manganese silicate; zirconium; aluminum; inoculant; deoxidation; sulphide capacity.

\section{Introduction}

It is well known that many efforts have been made to remove nonmetallic inclusions from molten steel because they cause many harmful effects on steel properties. However, the authors presented a new idea called "Oxides Metallurgy", in which oxide particles in steel are utilized as the nucleation sites of precipitates by controlling the size, the distribution and the nature of oxides. ${ }^{1,2)}$ Precipitates in steel exert various effects on steel properties. For example, small $\mathrm{MnS}$ restrains the grain growth of steel by a pinning effect on the grain boundaries. $\mathrm{MnS}$ also works as the transformation site of fine acicular ferrite and as the precipitation site of cementite. If we control the precipitates by using oxide particles, many steel properties can be improved.

From the standpoint described above, the authors have studied the behavior of $\mathrm{MnS}$ precipitation on oxide particles in low $\mathrm{S}$ steel in terms of precipitation ratio of $\mathrm{MnS}$ on oxide particles defined as the ratio of the number of oxide particles worked as the sites of MnS precipitation to the number of oxide particles in steel. It was observed that the ratio depended on the kind and the composition of oxides and that the ratio was higher in the case of Mn-silicate having a lower melting temperature and a higher sulphide capacity in the steel containing 1 mass $\%$ of $\mathrm{Mn}$ and $50 \mathrm{ppm}$ of S., ${ }^{3,4)}$ Based on these phenomena, the authors concluded the precipitation mechanism of $\mathrm{MnS}$ on oxide particles is as follows ${ }^{3,4)}$ : In molten steel, $\mathrm{S}$ distributes between liquid Mn-complex oxide and molten steel. As the temperature decreases and after the solidification of the steel, a small amount of $\mathrm{MnS}$ crystallizes on the surface of the oxide and works as an embryo for $\mathrm{MnS}$ precipitation. The $\mathrm{MnS}$ grows by $\mathrm{Mn}$ and $S$ diffusion in the steel.

However, the investigation was carried out only in the case of low $S$ steel, and a study in a wide range of $S$ content is necessary because $S$ content range of steel now in production is from a few to thousands ppm. In this study, the effects of $\mathrm{S}$ content on the MnS precipitation with several kinds of oxide nuclei were investigated during laboratory scale experiments.

\section{Experimental Procedures}

One $\mathrm{kg}$ of pure iron was melted by induction heating in a magnesia crucible under an Ar gas atmosphere. After adjusting the main composition at $1570^{\circ} \mathrm{C}(1843 \mathrm{~K}), 1 \mathrm{~g}$ of $\mathrm{Fe}_{2} \mathrm{O}_{3}$ was added to control initial oxygen content. Then deoxidizing elements were added. The melt was kept for $30 \mathrm{~s}$ after deoxidation and cooled in the crucible by switching the power off.

Chemical compositions of specimens are listed in Table 1. The amount of $\mathrm{S}$ was changed from 13 to $620 \mathrm{ppm}$ 
Table 1. Chemical compositions of specimens. (mass $\%$ )

\begin{tabular}{|c|c|c|c|c|c|c|c|c|c|}
\hline & C & Si & $\mathrm{Mn}$ & $S$ & $\mathrm{Ti}$ & $\mathrm{Zr}$ & $\mathrm{Al}$ & $N$ & 0 \\
\hline MS-1 & 0.11 & 0.18 & 0.91 & 0.0013 & 0.0075 & o. & 0. & 0.0023 & 0.0033 \\
\hline MS-2 & 0.11 & 0.18 & 0.90 & 0.0013 & 0 & 0.0054 & 0. & 0.0018 & 0.0042 \\
\hline MS-3 & 0.09 & 0.007 & 1.02 & 0.0030 & 0. & 0 & 0. & 0 & 0.0040 \\
\hline MS-4 & 0.09 & 0.21 & 1.03 & 0.0040 & 0 . & 0. & 0. & 0 . & 0.0030 \\
\hline MT-1 & 0.10 & 0. & 0.95 & 0.0040 & 0.0270 & 0 & 0. & 0. & 0.0073 \\
\hline$M T-2$ & 0.09 & 0. & 0.96 & 0.0064 & 0.0270 & o. & 0 & 0.0023 & 0.0098 \\
\hline MT-3 & 0.10 & 0. & 0.97 & 0.0129 & 0.0280 & 0. & 0. & 0.0007 & 0.0068 \\
\hline MT-4 & 0.10 & 0 & 0.99 & 0.0371 & 0.0290 & 0. & 0. & 0.0022 & 0.0068 \\
\hline$A L-1$ & 0.07 & 0.011 & 0.99 & 0.0070 & 0 & 0. & 0.0290 & 0.0023 & 0.0009 \\
\hline AL-2 & 0.08 & 0.011 & 0.98 & 0.0110 & 0 & 0 & 0.0290 & 0.0021 & 0.0016 \\
\hline$A L-3$ & 0.08 & 0.009 & 1.00 & 0.0530 & 0 & 0. & 0.0280 & 0.0030 & 0.0019 \\
\hline$A L=4$ & 0.08 & 0.010 & 1.01 & 0.0620 & 0. & 0. & 0.0300 & 0.0027 & 0.0013 \\
\hline AL-5 & 0.16 & 0. & 0.90 & 0.0060 & 0. & 0. & 0.0070 & $<.0005$ & 0.0018 \\
\hline AL-6 & 0.10 & 0. & 0.90 & 0.0060 & 0. & 0. & 0.0070 & $<.0005$ & 0.0018 \\
\hline AL-7 & 0.10 & 0.19 & 0.93 & 0.0040 & 0. & 0. & $<0.003$ & 0 & 0.0071 \\
\hline ZR-1 & 0.11 & 0. & 0.98 & 0.0040 & 0. & 0.0250 & 0. & 0. & 0.0085 \\
\hline ZR-2 & 0.10 & 0. & 0.96 & 0.0068 & 0. & 0.0250 & 0. & 0. & 0.0086 \\
\hline ZR-3 & 0.11 & 0. & 0.96 & 0.0388 & 0. & 0.0290 & 0. & o. & 0.0073 \\
\hline
\end{tabular}

and the deoxidation elements were $\mathrm{Al}, \mathrm{Zr}, \mathrm{Mn}-\mathrm{Si}$ and $\mathrm{Mn}-\mathrm{Ti}$. The samples were analyzed by a computer-aided, two-dimensional X-ray microanalyzer (CMA). The kinds and distributions of particles in the samples were determined from the characteristic X-ray images. The morphologies of the particles were observed by using a SEM with an energy dispersion analyzer.

On the characteristic X-ray image analysis, threshold values for identifying the particles, based on a previous work, ${ }^{5)}$ were as follows: For $\mathrm{MnS}$, the threshold value of $\mathrm{Mn}$ was the value of $\mathrm{X}$-ray intensity corresponding to the concentration $1.32 C_{\mathrm{AV}}$ and that of $\mathrm{S}$ was $X_{\mathrm{AV}}+5 \sigma$ of X-ray intensity $\left(C_{\mathrm{AV}}\right.$ : average concentration of an element; $X_{\mathrm{AV}}, \sigma$ : average and standard deviation of X-ray intensity). For oxide particles, the threshold value was also $X_{\mathrm{AV}}+5 \sigma$ of X-ray intensity of each deoxidizing element.

\section{Mathematical Model for MnS Formation}

The mathematical model used here was developed by Ueshima et al. ${ }^{5,6)}$ In the model, a hexagonal dendrite model as shown in Fig. 1 is assumed, and solute distribution between liquid and solid during solidification is calculated at each temperature step taking into consideration the back diffusion of elements in the solid. Delta/gamma transformation is also considered in the model. The precipitation of MnS starts when the concentration product of $\mathrm{Mn}$ and $\mathrm{S}$ reaches the value of equilibrium solubility product, and the $\mathrm{MnS}$ grows spherically under the diffusion control of $\mathrm{Mn}$ and $\mathrm{S}$ in the solid. The equilibrium solubility product values of $\mathrm{Mn}$ and $\mathrm{S}$ are calculated by the Eqs. (1) and (2) obtained by attaching the correction term of $\mathrm{Si}$ content to the equations derived by Wriedt et al. ${ }^{7)}$ and Turkdogan et $a l^{8)}$

$$
\begin{aligned}
& \log [\mathrm{mass} \% \mathrm{Mn}][\mathrm{mass} \% \mathrm{~S}](\delta)=-10590 / T+4.0302 \\
& \quad-0.07[\mathrm{mass} \% \mathrm{Si}]
\end{aligned}
$$

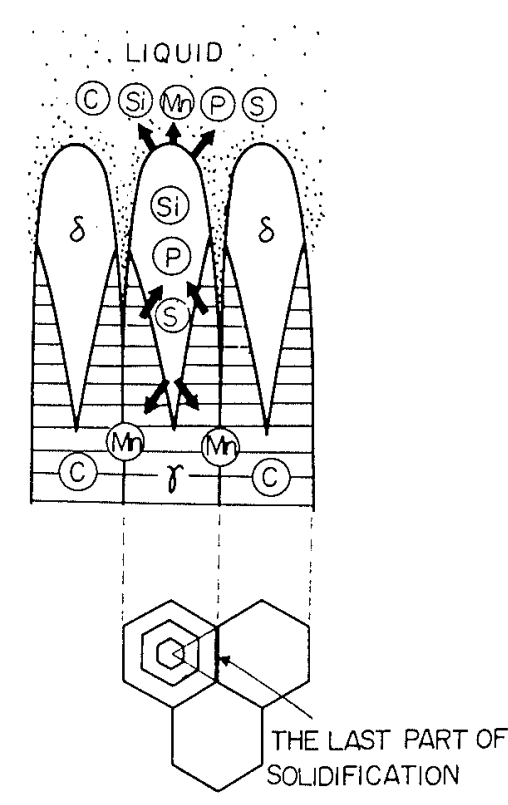

Fig. 1. Schematic drawing of the longitudinal and transverse cross section of dendrites. ${ }^{6)}$

$$
\begin{aligned}
& \log [\text { mass } \% \mathrm{Mn}][\text { mass } \% \mathrm{~S}](\gamma)=-90080+2.929 \\
& -(-215 / T+0.097)[\text { mass } \% \mathrm{Mn}]-0.07[\mathrm{mass} \% \mathrm{Si}]
\end{aligned}
$$

The values of physical properties used for the calculation are listed in Table 2. ${ }^{9-12)}$ In the calculation, $\mathrm{Mn}$ concentration was kept at 1 mass $\%$ and $\mathrm{S}$ content was varied nine times from 10 to $3200 \mathrm{ppm}$. The distance among the sites for $\mathrm{MnS}$ precipitation was $100 \mu \mathrm{m}$, which was constant and did not depend on the kind of oxides. The distance among oxides, $100 \mu \mathrm{m}$ corresponds to that obtained in the case of Al-deoxidation. The condition for the calculation is shown in Table 3. The cooling rate was $35^{\circ} \mathrm{C} / \mathrm{min}\left(0.58^{\circ} \mathrm{C} / \mathrm{s}\right)$ and the primary dendrite arm spacing was $300 \mu \mathrm{m}$; these corresponded to the values obtained from the $1 \mathrm{~kg}$ ingot experiments. 
Table 2. Equilibrium distribution coefficients and diffusion coefficients of elements.

\begin{tabular}{|c|c|c|c|c|c|}
\hline Element & $k^{\delta / L}$ & $k^{\gamma / \Lambda}$ & $\mathrm{k}^{\gamma / \delta}$ & $D^{6}\left(\mathrm{~cm}^{2} / \mathrm{s}\right)$ & $D^{\gamma}\left(\mathrm{cm}^{2 / \mathrm{s}}\right)$ \\
\hline C & 0.19 & 0.34 & 1.79 & $0.0127 \exp (-19450 / \mathrm{RT})$ & $0.0761 \exp (-32160 / R T)$ \\
\hline $\mathrm{Si}$ & 0.77 & 0.52 & 0.68 & $8.0 \exp (-59500 / \mathrm{RT})$ & $0.30 \exp (-60100 / \mathrm{RT})$ \\
\hline $\mathrm{Mn}$ & 0.76 & 0.78 & 1.03 & $0.76 \exp (-53640 / \mathrm{RT})$ & $0.055 \exp (-59600 / \mathrm{RT})$ \\
\hline $\mathrm{P}$ & 0.23 & 0.13 & 0.57 & $2.9 \exp (-55000 / R T)$ & $0.010 \exp (-43700, R T)$ \\
\hline s & 0.05 & 0.035 & 0.70 & $4.56 \exp (-51300 / R T)$ & $2.4 \exp (-53400 / R T)$ \\
\hline
\end{tabular}

Table 3. Conditions for the calculation of MnS formation.

\begin{tabular}{|c|c|c|c|c|c|}
\hline Composition & c & $\mathrm{Si}$ & $\mathrm{Mn}$ & $\mathrm{P}$ & $\mathrm{s}$ \\
\hline (mass\%) & 0.1 & 0.001 & 1.0 & 0.001 & $0.001-0.320$ \\
\hline Cooling rate & \multicolumn{3}{|c|}{$35^{\circ} \mathrm{C} / \mathrm{min}$} & \multicolumn{2}{|c|}{$\left(0.58^{\circ} \mathrm{C} / \mathrm{s}\right)$} \\
\hline \multicolumn{3}{|c|}{ Primary dendrite arm spacing } & & \multicolumn{2}{|c|}{$300 \mu \mathrm{m}$} \\
\hline
\end{tabular}
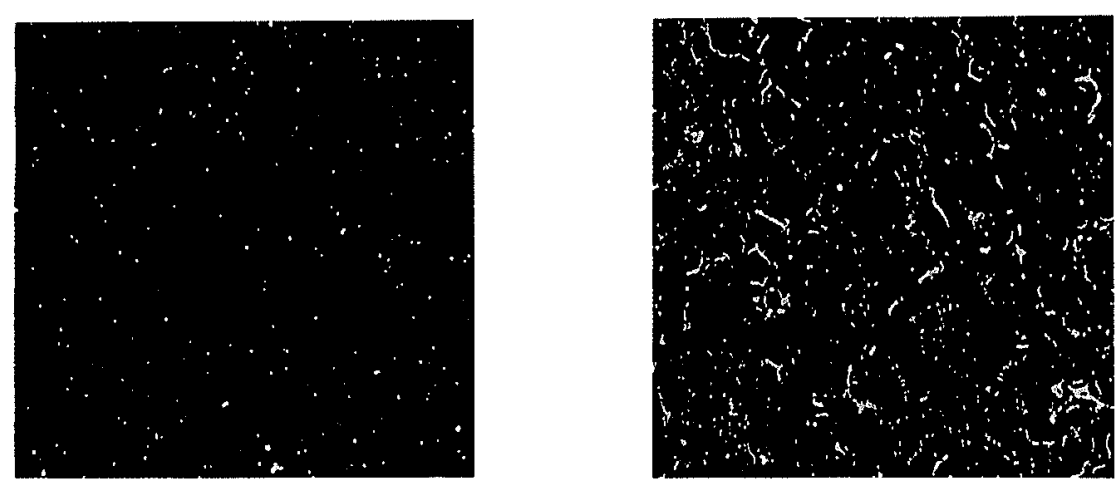

\section{S=70ppm $\stackrel{\longmapsto}{500 \mu m} \quad$ S=530ppm}

Fig. 2. Distribution of oxides and sulphides. (by $\mathrm{CMA} / 1 \mathrm{mass} \% \mathrm{Mn}-0.03$ mass $\% \mathrm{Al}$ )

\section{Results}

\subsection{MnS Formation Experiments}

Figure 2 shows the distribution of oxide particles and $\mathrm{MnS}$ particles in the cases of 70 and $530 \mathrm{ppm} \mathrm{S}$ with Al-deoxidation obtained by using the CMA. The red network structure indicates $\mathrm{Mn}$ microsegregation, blue spots represent the oxide particles, and yellow spots show $\mathrm{MnS}$. As a result, white spots represent the $\mathrm{MnS}$ precipitated on the oxide particles. In the case of $70 \mathrm{ppm}$ of $S$, in addition to the white spots, many blue spots are seen, which represent the oxide particles without $\mathrm{MnS}$ precipitation. In the case of $530 \mathrm{ppm}$ of $\mathrm{S}$, a lot of stringlike $\mathrm{MnS}$ are visible, and the white spots that show the $\mathrm{MnS}$ precipitated on oxides can also be seen. The black area around the stringlike $\mathrm{MnS}$, resulted from the decrease in $\mathrm{Mn}$ concentration in the inter-dendritic region caused by the formation of $\mathrm{MnS}$ as reported by Ueshima et $a l .^{13)}$ in the case of the steel containing $1 \mathrm{mass} \%$ of $\mathrm{Mn}$ and $3200 \mathrm{ppm}$ of S.

The result of quantitative analysis of the photograph is given in Table 4 . The number of oxide and $\mathrm{MnS}$ particles were counted in the area of $1.5 \times 1.5 \mathrm{~mm}^{2}$. The $\mathrm{MnS}$ precipitation ratio on oxides is defined as the number of oxide particles with $\mathrm{MnS}$ precipitation divided by the total number of oxides observed, which indicates the ratio of oxide particles being as the precipitation sites
Table 4. Number of oxide and MnS particles in the steel having various $S$ content and deoxidized with various deoxidation elements.

\begin{tabular}{|c|c|c|c|c|c|}
\hline \multirow{2}{*}{$\begin{array}{l}\text { Deoxidation } \\
\text { elements }\end{array}$} & \multirow{2}{*}{$\begin{array}{c}5 \\
(p p m)\end{array}$} & \multicolumn{3}{|c|}{$\begin{array}{l}\text { Number of particles } \\
\{1 / 1.5 \mathrm{~mm} \times 1.5 \mathrm{~mm}\}\end{array}$} & \multirow{2}{*}{$\begin{array}{c}\text { Precipitation } \\
\text { ratio of MnS } \\
(\%) \\
(* 3 / * 1) \times 100\end{array}$} \\
\hline & & $\begin{array}{c}\text { Oxides } \\
* 1\end{array}$ & $\begin{array}{c}\text { MnS } \\
* 2\end{array}$ & $\begin{array}{l}\text { MnS on oxide } \\
* 3\end{array}$ & \\
\hline $\mathrm{Mn}-\mathrm{Si}(1)$ & 13 & 75 & 27 & 26 & 34.7 \\
\hline $\operatorname{Mn}-\mathrm{Si}\langle 2\rangle$ & 13 & 278 & 80 & 74 & 26.6 \\
\hline $\mathrm{Mn}-\mathrm{Si}(3)$ & 30 & 176 & 228 & 152 & 86.4 \\
\hline $\operatorname{Mn}-\mathrm{Si}(4)$ & 40 & 143 & 179 & 110 & 76.9 \\
\hline Mn-Ti(1) & 40 & 304 & 197 & 186 & 61.2 \\
\hline $\mathrm{Mn}-\mathrm{Ti}(2)$ & 64 & 354 & 262 & 239 & 67.5 \\
\hline $\mathrm{Mn}-\mathrm{Ti}(3)$ & 129 & 292 & 288 & 255 & 87.3 \\
\hline $\mathrm{Mn}-\mathrm{Ti}(4)$ & 371 & 370 & 461 & 353 & 95.4 \\
\hline Al $(1)$ & 70 & 299 & 223 & 124 & 41.5 \\
\hline$A \mid\langle 2\}$ & 110 & 139 & 219 & 116 & 83.5 \\
\hline $\mathrm{Al}(3)$ & 530 & 171 & 1012 & 142 & 83.0 \\
\hline Al (4) & 620 & 98 & 581 & 83 & 84.7 \\
\hline $\mathrm{Al}(10 \mathrm{~kg}-1)$ & 60 & 374 & 180 & 115 & 30.7 \\
\hline AI $(10 \mathrm{~kg}-2\}$ & 60 & 450 & 245 & 174 & 37.8 \\
\hline Al (Ueshima) & 40 & 155 & - & 37 & 23.9 \\
\hline $\mathrm{Zr}(1)$ & 40 & 677 & 174 & 174 & 25.7 \\
\hline $\operatorname{Zr}(2)$ & 68 & 490 & 292 & 250 & 51.0 \\
\hline $\operatorname{Zr}(3)$ & 388 & 520 & 838 & 511 & 98.3 \\
\hline
\end{tabular}

of $\mathrm{MnS}$. The table also shows the result of $10 \mathrm{~kg}$ ingot experiment carried out by the author and the data for $1 \mathrm{~kg}$ ingot experiment obtained by Ueshima et al. ${ }^{5)}$

The relationship between the precipitation ratio of 
$\mathrm{MnS}$ and $\mathrm{S}$ content obtained from Table 4 is shown in Fig. 3. In the case of Al-deoxidation, the precipitation ratio in low $\mathrm{S}$ region was 20 to $40 \%$, which was very low; however, the ratio reached $85 \%$ in the $\mathrm{S}$ region over $100 \mathrm{ppm}$. The result of $10 \mathrm{~kg}$ ingot experiment and the data from Ueshima et al. ${ }^{5)}$ were also on the same curve as this study. The same tendency was seen in the case of $\mathrm{Zr}$-deoxidation. In the case of $\mathrm{Mn}$-Si-deoxidation, the precipitation ratio was about $85 \%$, which was higher even in the low $\mathrm{S}$ region at $40 \mathrm{ppm}$, and the ratio fell to $30 \%$ in the very low $S$ region at $13 \mathrm{ppm}$. In the case of Mn-Ti-deoxidation, the value was 60 to $70 \%$ when the $\mathrm{S}$ content was below $100 \mathrm{ppm}$ and rose when the $\mathrm{S}$ was over 100 ppm.

Figure 4 shows typical morphologies of oxide and $\mathrm{MnS}$ particles in the cases of Al-deoxidation and Mn-Tideoxidation. In the case of $70 \mathrm{ppm} \mathrm{S}$ with Al-deoxidation (1), $\mathrm{Al}_{2} \mathrm{O}_{3}$ with complicated shape was seen, and when the $\mathrm{S}$ was $530 \mathrm{ppm}$ (2), the whole particles were $\mathrm{MnS}$, and no oxide was detected. However, it seems that Al-oxides were inside of the $\mathrm{MnS}$ as the precipitation sites of the $\mathrm{MnS}$, because a slight signal of $\mathrm{Al}$ was observed in the MnS by EDX analysis. In the case of $64 \mathrm{ppm} \mathrm{S}$ with Mn-Ti-deoxidation (3), Mn-Ti-oxide particle was seen and $\mathrm{MnS}$ was observed partly in the lower part of the oxide in the photograph. The data of
EDX analysis of the $\mathrm{MnS}$ included week signals of $\mathrm{Mn}$ and $\mathrm{Ti}$. It is considered that the signals came from the oxide behind and around the $\mathrm{MnS}$. When the $\mathrm{S}$ was $371 \mathrm{ppm}$ (4), the black part in the center of the particle

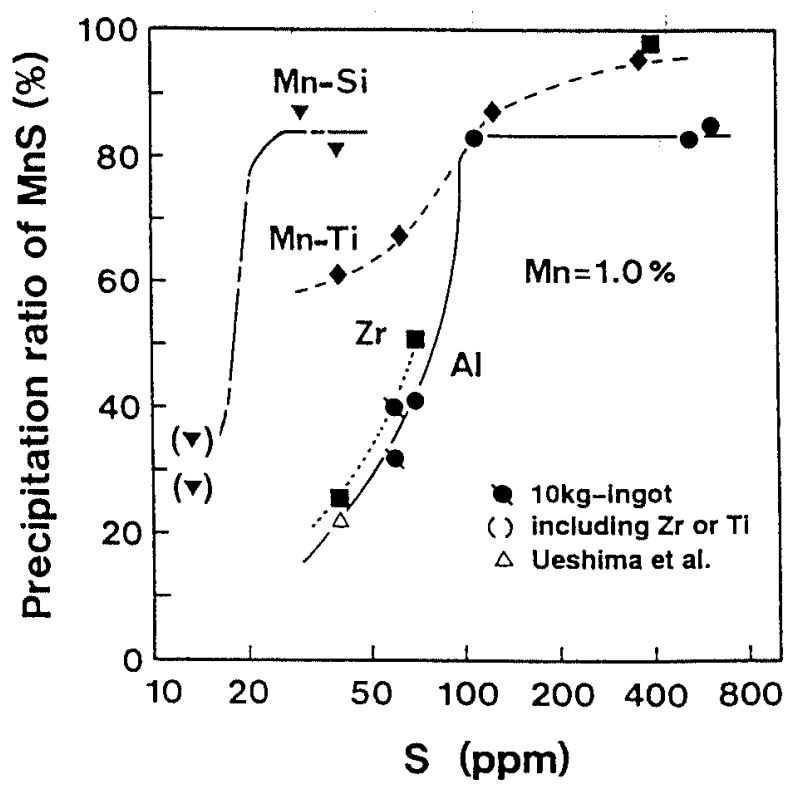

Fig. 3. Change in the precipitation ratio of $\mathrm{MnS}$ with $\mathrm{S}$ content and with the kind of deoxidation elements.
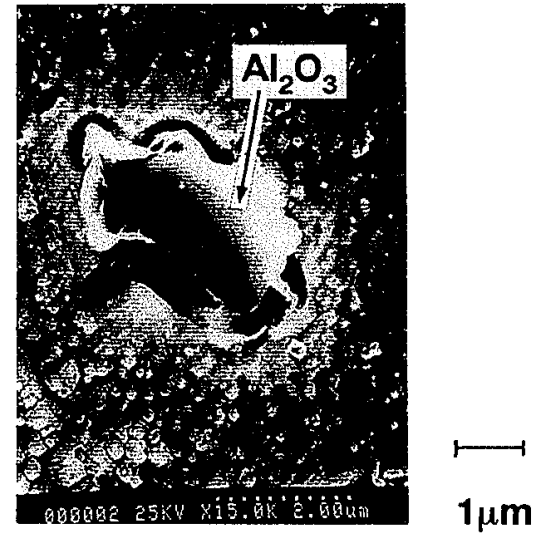

(1) Al-deoxidation (S=70ppm)
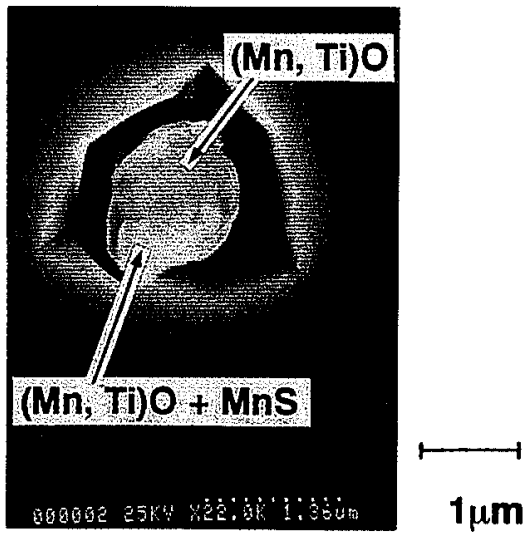

(3) Mn-Ti-deoxidation (S=64ppm)

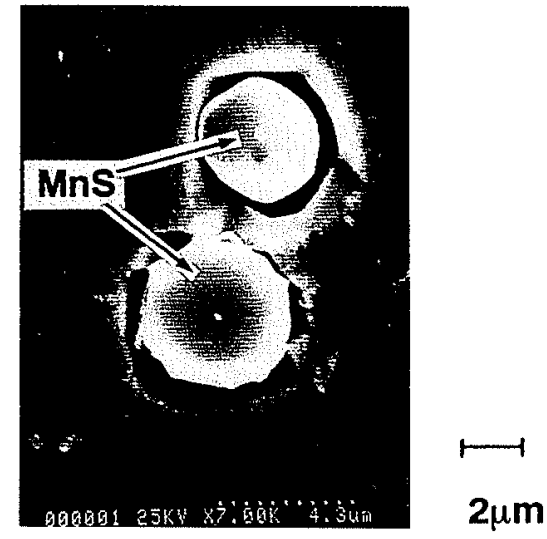

(2) Al-deoxidation ( $S=530 \mathrm{ppm}$ )

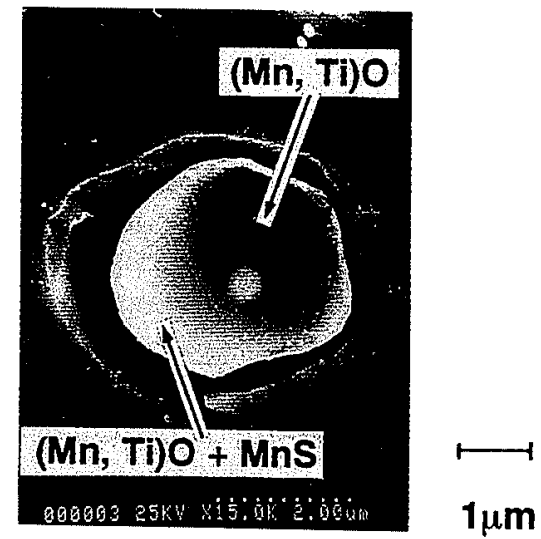

(4) Mn-Ti-deoxidation (S=371 ppm)

Fig. 4. SEM images of oxide and MnS particles. 
was $\mathrm{Mn}$-Ti-oxide, and $\mathrm{MnS}$ surrounded it.

\subsection{Calculation of MnS Formation}

The relationship between the temperature of the beginning of $\mathrm{MnS}$ formation and $\mathrm{S}$ content calculated by the mathematical model is shown in Fig. 5. In the calculation, Mn was kept at 1 mass\%. Liquidus and solidus temperatures and the starting temperature of the $\delta / \gamma$ transformation are also indicated in Fig. 5. In the low $\mathrm{S}$ region, $\mathrm{MnS}$ precipitates in $\gamma$ phase, and the beginning temperature of $\mathrm{MnS}$ precipitation increases according to the increase of $\mathrm{S}$ content and reaches $\delta / \gamma$ transformation beginning temperature. At $100 \mathrm{ppm}$ of $\mathrm{S}$, $\mathrm{MnS}$ precipitates in $\delta$ phase before the transformation, and in the region of $S$ above $400 \mathrm{ppm}$, crystallization of $\mathrm{MnS}$ occurs in the inter-dendritic liquid region after the precipitation in $\delta$ phase. Figure 6 indicates the amount of $\mathrm{MnS}$ formation for various $\mathrm{S}$ content. The amount was represented as the $\mathrm{S}$ amount of $\mathrm{MnS}$ formed by the crystallization from liquid steel having high $\mathrm{Mn}$ and $\mathrm{S}$ concentration in the inter-dendritic region and by the precipitation from solid steel during cooling. The amount of crystallized $\mathrm{MnS}$ and precipitated $\mathrm{MnS}$ was derived by the calculation model. The amount of crystallized $\mathrm{MnS}$ is large when $\mathrm{S}$ content is over $800 \mathrm{ppm}$. Figure 7 shows the ratio of crystallization amount of $\mathrm{MnS}$ to the total amount of MnS. In Fig. 7, the ratio increases with the increase of $\mathrm{S}$ content, and its value is $89 \%$ at 3200 ppm of $\mathrm{S}$.

\section{Discussion}

\subsection{Mechanism of MnS Formation with Oxide Nuclei}

From Fig. 3, the behavior of MnS precipitation on oxide particles in the case of 1 mass $\% \mathrm{Mn}$ is characterized according to $\mathrm{S}$ content as follows:

(1) $\mathrm{S}<0.002$ mass $\%$ : The number of $\mathrm{MnS}$ precipitating on oxides was small in any kinds of oxide.

(2) $0.002 \leqq \mathrm{~S}<0.01$ mass $\%$ : The precipitation ratio was high in some kinds of oxide.

(3) $\mathrm{S} \geqq 0.01$ mass $\%$ : The ratio was large in almost all oxides. That means they worked as the precipitation sites of $\mathrm{MnS}$.

Several experimental results and discussion were shown in the Refs. 3), 4) by the authors in the case of (2). The preferable oxides for the $\mathrm{MnS}$ precipitation sites were $\mathrm{Mn}$-complex oxides having lower melting temperatures and higher sulphide capacities, such as $\mathrm{Mn}$-silicate and $\mathrm{Mn}$-aluminate in the steel containing 50 to $100 \mathrm{ppm}$ of $\mathrm{S}$. Based on these phenomena, the authors concluded the precipitation mechanism of $\mathrm{MnS}$ on oxide particles as follows: In molten steel, $\mathrm{S}$ distributes between liquid Mn-complex oxide and the molten steel. As the temperature decreases and after the solidification of the steel, a small amount of $\mathrm{MnS}$ crystallizes on the surface of the oxide and works as an embryo of $\mathrm{MnS}$ precipitation. The $\mathrm{MnS}$ grows by the diffusion of $\mathrm{Mn}$ and $\mathrm{S}$ in the steel.

Sano $^{14)}$ and Hasegawa et al. ${ }^{15)}$ reported Mn-silicate had large solubility of $\mathrm{MnS}$. Based on the data, $\mathrm{MnS}$ formation from $\mathrm{Mn}$ and $\mathrm{S}$ diffusion at the surface of

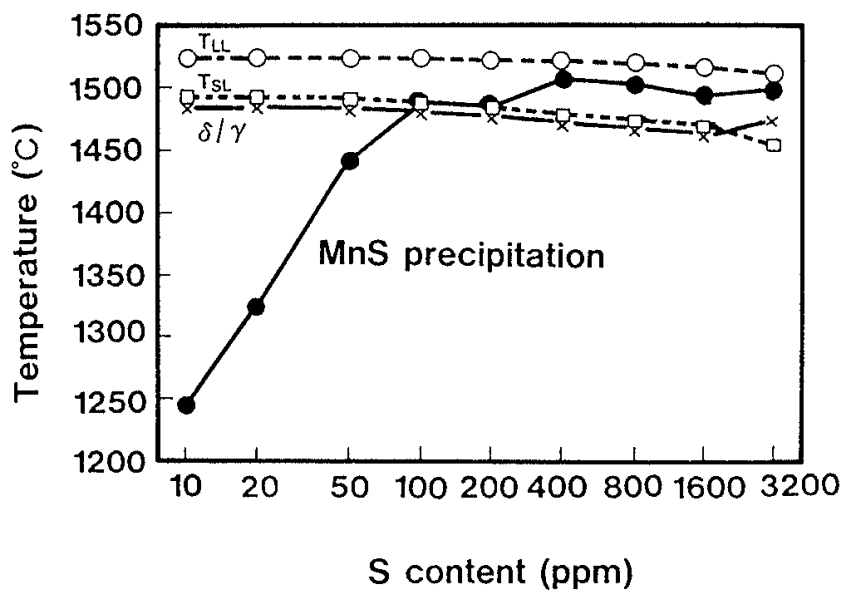

Fig. 5. Starting temperature of precipitation or crystallization of $\mathrm{MnS}$. (estimated)

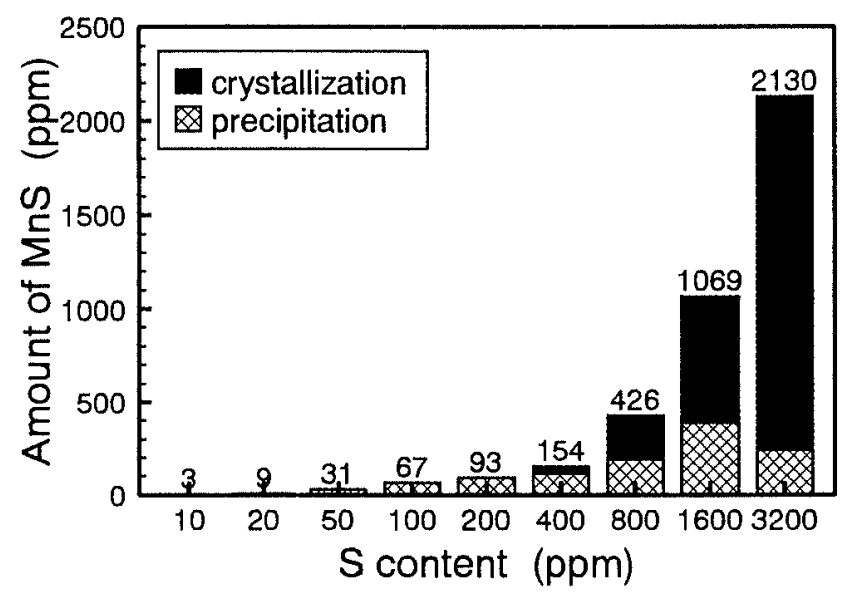

Fig. 6. Change in the amount of $\mathrm{S}$ as $\mathrm{MnS}$. (estimated)

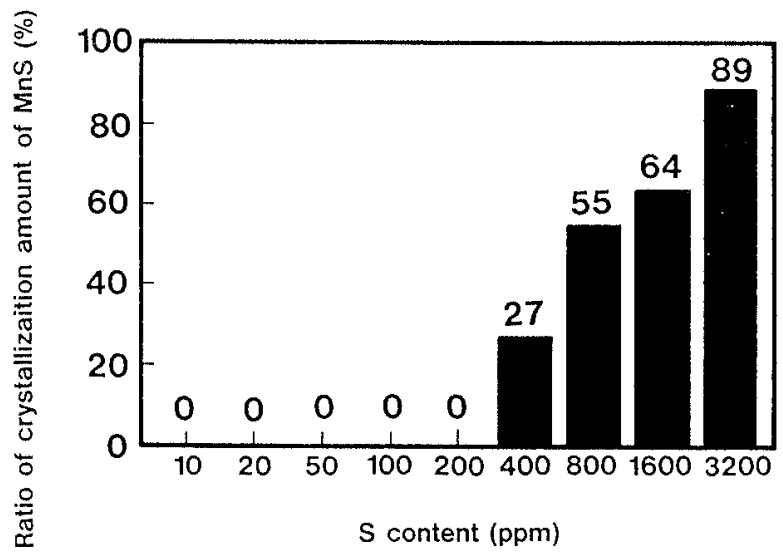

Fig. 7. Ratio of the MnS amount formed by crystallization from molten steel. (estimated)

Mn-silicate oxide particle and dissolution of the MnS in the oxide after solidification of steel seem to be promoted because of low activity of $\mathrm{MnS}$ in such liquid oxide particles (the lowest melting temperature of $\mathrm{Mn}$-silicate is about $1250^{\circ} \mathrm{C}(1523 \mathrm{~K})$ ). As the temperature decreases, the oxide solidifies and $\mathrm{MnS}$ crystallizes on the surface of the oxide. Therefore, $\mathrm{Al}$-oxide and $\mathrm{Zr}$-oxide are not suitable as the precipitation sites of $\mathrm{MnS}$ because they seem to have no or a little solubility of $\mathrm{Mn}$ and $\mathrm{S}$.

In Fig. 3, Mn-Ti-oxide had 60 to $70 \%$ of the pre- 
cipitation ratio in the range of $\mathrm{S}$ content from 20 to $100 \mathrm{ppm}$. Titanium-oxide in steel is regarded as $\mathrm{Ti}_{3} \mathrm{O}_{5}$ or $\mathrm{Ti}_{2} \mathrm{O}_{3},{ }^{16)}$ but phase diagrams and the data of sulphide capacity for $\mathrm{MnO}-\mathrm{Ti}_{3} \mathrm{O}_{5}$ and $\mathrm{MnO}-\mathrm{Ti}_{2} \mathrm{O}_{3}$ are not available. Mn-Ti-oxides seem to have high sulphide capacity because of their higher precipitation ratio of MnS. Recently, Morita et al. ${ }^{17)}$ reported there was liquid phase in wide range of $\mathrm{MnO}-\mathrm{Ti}_{2} \mathrm{O}_{3}$ system at $1873 \mathrm{~K}$. Low melting temperature is one of the conditions for oxides to be better site of $\mathrm{MnS}$ precipitation. Therefore, in the case of (2), it is desirable to select the oxides having high sulphide capacities and low melting temperatures as the precipitation sites of $\mathrm{MnS}$ for the fine dispersion of $\mathrm{MnS}$.

In the region of (1), the precipitation ratio becomes low even in the case of $\mathrm{Mn}$-Si-deoxidation, because it is difficult to form an embryo for $\mathrm{MnS}$ precipitation on oxides for the lack of $\mathrm{S}$ amount dissolved in the oxides. Moreover, the growth of $\mathrm{MnS}$ is not expected because the precipitation temperature is below $1325^{\circ} \mathrm{C}(1598 \mathrm{~K})$ from Fig. 5, which makes the diffusion of $\mathrm{Mn}$ and $\mathrm{S}$ rather slow. However, from Table 4, the number of $\mathrm{MnS}$ increased when the number of oxides was large even in the case of $13 \mathrm{ppm}-\mathrm{S}$. Therefore, it is possible to promote the diffusion by the dispersion of fine oxide particles having high value of precipitation ratio so that the distance among the precipitation sites is shortened. It is necessary to find the oxides having a higher $\mathrm{S}$ capacity than that of Mn-silicate for the fine dispersion of $\mathrm{MnS}$ in this $S$ region (1).

In the $\mathrm{S}$ region of (3), $\mathrm{MnS}$ precipitates on most of the oxide particles in the steel, and the precipitation does not depend on the kind of oxides. From the result of the calculation shown in Fig. 5, the temperature at which $\mathrm{MnS}$ precipitation begins reaches the $\delta / \gamma$ transformation temperature and $\mathrm{MnS}$ precipitated in $\delta$ phase in the $\mathrm{S}$ region above $100 \mathrm{ppm}$. However, it is difficult to explain the $\mathrm{MnS}$ behavior in the region (3) by the $\mathrm{MnS}$ precipitation in $\delta$ phase. It is better to consider that the supersaturation owing to high $[\mathrm{Mn}] \times[\mathrm{S}]$ product value leads to the heterogeneous nucleation of $\mathrm{MnS}$ regardless of the kind of the nuclei.

From the calculation result, crystallization of $\mathrm{MnS}$ from liquid steel in the inter-dendritic region occurs when $\mathrm{S}$ content is more than $400 \mathrm{ppm}$ as shown in Fig. 7. Figure 8 presents the number of $\mathrm{MnS}$ with oxides and without oxides obtained by CMA analysis in the cases of Aldeoxidation and $\mathrm{Mn}$-Ti-deoxidation. In the figure, the number of the $\mathrm{MnS}$ without oxides is large when the $\mathrm{S}$ content is over $530 \mathrm{ppm}$. Though all the $\mathrm{MnS}$ without oxides does not represent the sole $\mathrm{MnS}$ because of the precision limit of the CMA measurement, it seems to be possible that the solidification front also works as the precipitation site of $\mathrm{MnS}$ as do the oxide particles. However, fine $\mathrm{MnS}$ dispersion could be obtained if the $\mathrm{MnS}$ precipitation in $\delta$ phase is promoted by using the oxide particles dispersed with very short distances, before the crystallization of $\mathrm{MnS}$ starts from liquid in the inter-dendritic region.

Therefore, in the region (3), the oxide that tends to disperse finely itself in steel should be selected because
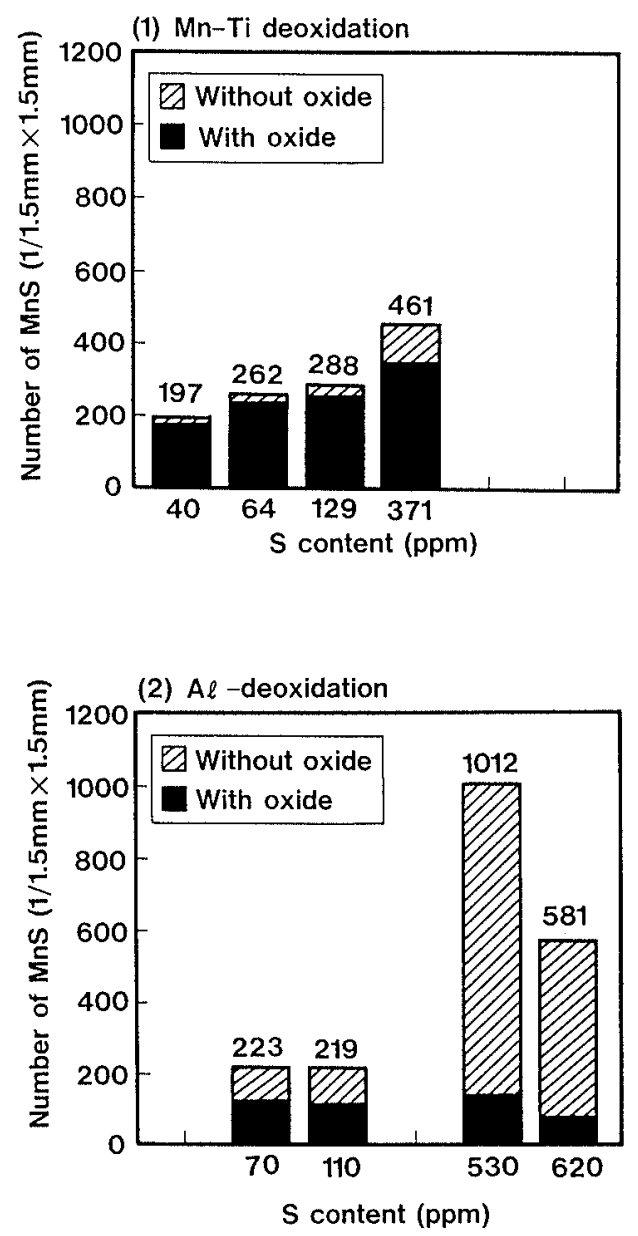

Fig. 8. Change in the number of $\mathrm{MnS}$ in the steel having various $\mathrm{S}$ content and deoxidized with various deoxidation elements.

any kind of oxides could be the precipitation site of $\mathrm{MnS}$, regardless of whether the oxide has high sulphide capacity.

\subsection{Calculation of $\mathrm{MnS}$ Formation Considering the Precipitation Ratio}

Based on the discussion and the experimental data described above, some calculations were made by using the mathematical model for $\mathrm{MnS}$ formation considering the nuclei of $\mathrm{MnS}$ precipitation. To consider the oxide nuclei, the number of precipitation sites of $\mathrm{MnS}$ is determined by the number of oxide particles multiplied by the precipitation ratio, which is determined according to the kind of oxide and the $\mathrm{S}$ content.

Two ways of determining the precipitation site of $\mathrm{MnS}$ were used in the calculation based on the experimental results: First, the number of the precipitation sites, which is the oxide number, is changed but the precipitation ratio is kept at $100 \%$ in the full range of $S$, and second, the precipitation ratio is changed according to the $S$ content and the number of oxides were kept as 200 $\left(1 / 1.5 \times 1.5 \mathrm{~mm}^{2}\right)$. The former case corresponds to that of $\mathrm{Mn}$-Ti-deoxidation and the latter case corresponds to that of Al-deoxidation. Table 5 shows the conditions for the calculations.

The relationship between the average diameter of $\mathrm{MnS}$ and $\mathrm{S}$ content obtained by the calculation is shown in Fig. 9. When the oxide number changes as shown in (1), 
Table 5. Condition for the calculation of MnS diameter taking into consideration of the oxide nucleus.

\begin{tabular}{|c|c|c|c|c|c|}
\hline \multirow{2}{*}{$\begin{array}{c}\text { Composition } \\
\text { (mass\%) }\end{array}$} & c & $\mathrm{Si}$ & $\mathrm{Mn}$ & $\mathbf{P}$ & $s$ \\
\hline & 0.1 & 0.001 & 1.0 & 0.001 & $0.002-0.080$ \\
\hline Cooling rate & \multicolumn{5}{|c|}{$35^{\circ} \mathrm{C} / \mathrm{min}$} \\
\hline \multicolumn{3}{|c|}{ Primary dendrite arm spacing } & \multicolumn{3}{|c|}{$300 \mu \mathrm{m}$} \\
\hline \multicolumn{2}{|c|}{$\begin{array}{r}\text { Number of MnS site : N } \\
\qquad(1 / 1.5 \times 1.5 \mathrm{~mm})\end{array}$} & \multirow{2}{*}{\multicolumn{4}{|c|}{$\begin{array}{r}\text { (1) } \mathrm{N}=50,200,400,800, \quad R=100 \% \\
\text { (2) } \mathrm{N}=200, \mathrm{R} \text { : changed based on } \\
\text { the experimental data }\end{array}$}} \\
\hline Precipitation ratio & $: \mathrm{R}$ & & & & \\
\hline
\end{tabular}

(1) Mn-Ti-deoxidation

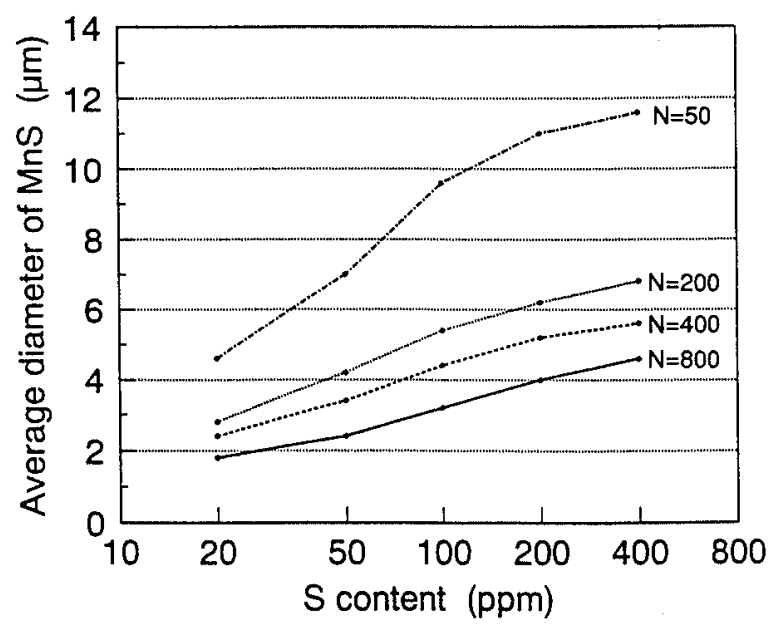

(2) Al-deoxidation

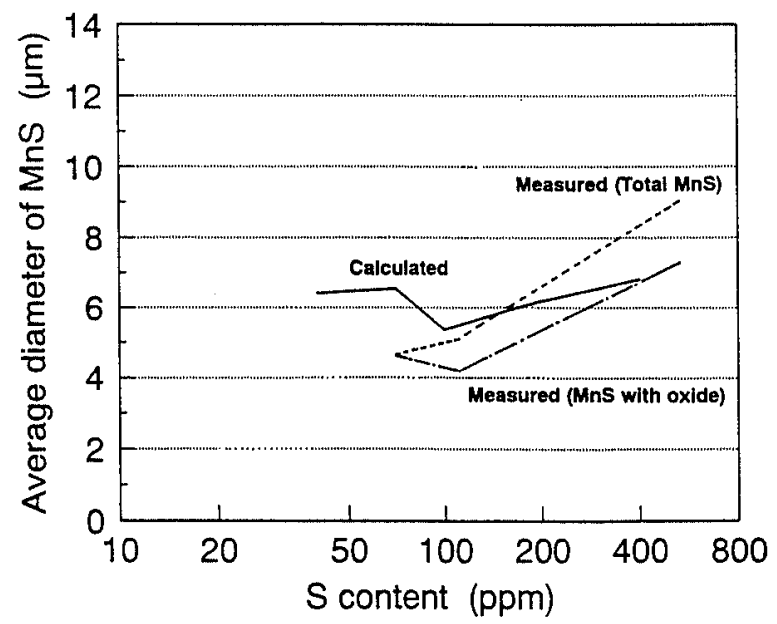

Number of MnS site : $\mathrm{N}(1 / 1.5 \times 1.5 \mathrm{~mm})$, Precipitation ratio : $\mathrm{R}$

(1)Mn-Ti-deoxidation: $\mathrm{N}=50,200,400,800, \mathrm{R}=100 \%$

(2)Al-deoxidation: $\mathrm{N}=200, \mathrm{R}$ : changed based on the experimental data

Fig. 9. Change in the average diameter of $\mathrm{MnS}$ in various conditions of precipitation sites. (estimated)

the average diameter of $\mathrm{MnS}$ increases with the increase of $\mathrm{S}$ content and decreases as the number of oxides becomes large. Therefore controlling the number of oxide particles is important for getting the appropriate diameter of $\mathrm{MnS}$.

On the other hand, in the case of varying the precipitation ratio (2), the diameter does not change below $70 \mathrm{ppm}$ of $\mathrm{S}$ because of the competition of the following effects: a) The diameter becomes small according to the increase of $S$ content because the precipitation sites increase. b) The diameter becomes large according to the increase of $\mathrm{S}$ content because of the increase of the $[\mathrm{Mn}] \times[\mathrm{S}]$ value. In the $\mathrm{S}$ content range from 70 to $100 \mathrm{ppm}$, the diameter decreases because of the effect of increasing the number of precipitation sites. On the other hand, in the case of more than $100 \mathrm{ppm}$ $\mathrm{S}$, the diameter increases because the precipitation ratio is kept constant as $100 \%$ and the $[\mathrm{Mn}] \times[\mathrm{S}]$ increases. In Fig. 9 (2), the average diameter of $\mathrm{MnS}$ (total $\mathrm{MnS}$ or $\mathrm{MnS}$ with oxides) obtained by Al-deoxidation experiment is plotted. There is a minimum point at $110 \mathrm{ppm} \mathrm{S}$ in the case of the average diameter of the $\mathrm{MnS}$ with oxides, and this agrees with the results of the calculation.

\section{Conclusions}

MnS formation experiments were carried out by deoxidizing with various deoxidation elements and changing $\mathrm{S}$ content to clarify the effect of $\mathrm{S}$ content on the MnS precipitation with various kinds of oxide nuclei. The experimental data and discussion yielded the following results.

(1) The behavior of $\mathrm{MnS}$ precipitation on oxide particles in the case of 1 mass $\%$ of $\mathrm{Mn}$ was characterized according to $\mathrm{S}$ content as follows:

(a) $\mathrm{S}<0.002$ mass $\%$ : The number of $\mathrm{MnS}$ precipitating on oxides was small in any kinds of oxide.

(b) $0.002 \leqq \mathrm{~S}<0.01 \mathrm{mass} \%$ : The precipitation ratio was high in some kinds of oxides.

(c) $\mathrm{S} \geqq 0.01$ mass $\%$ : The ratio was high in almost all the oxides. That means they worked as the precipitation sites of $\mathrm{MnS}$.

(2) For the uniform dispersion of fine $\mathrm{MnS}$, it is effective to use an oxide having a high sulphide capacity and a low melting temperature in the case of low $\mathrm{S}$ range below $100 \mathrm{ppm}$, and it is better to select the oxide which tends to disperse finely in steel in the case of higher $\mathrm{S}$ region above $100 \mathrm{ppm}$.

(3) The average diameter of $\mathrm{MnS}$ calculated by using a mathematical model considering the oxide nuclei with the precipitation ratio according to $\mathrm{S}$ content agrees well with the experimental data.

\section{Acknowledgements}

The authors are grateful to the late Dr. J. Takamura, a professor emeritus of Kyoto University, Dr. T. Fuwa, a professor emeritus of Tohoku University, Dr. Y. Iguchi, a professor of Tohoku University and Dr. H. Kajioka, an executive adviser of Nippon Steel Corporation for their many stimulating discussions.

\section{REFERENCES}

1) J. Takamura and S. Mizoguchi: Proc. Sixth Int. Iron and Steel Congress, Vol. 1, ISIJ, Tokyo, (1990), 591.

2) S. Mizoguchi and J. Takamura: Proc. Sixth Int. Iron and Steel Congress, Vol. 1, ISIJ, Tokyo, (1990), 598.

3) M. Wakoh, T. Sawai and S. Mizoguchi: Tetsu-to-Hagané, 78 (1992), 1697.

4) M. Wakoh, T. Sawai and S. Mizoguchi: Proc. of the Int. Symp.; Second Canada-Japan Symp. on Modern Steelmaking and 
ISIJ International, Vol. 36 (1996), No. 8

Casting Techniques, ed. by J. J. Jonas, J. D. Boyd and N. Sano, Toronto, Ontario, Aug. 20-25, (1994), 39-49.

5) Y. Ueshima, H. Yuyama, S. Mizoguchi and H. Kajioka: Tetsu-to-Hagané, 75 (1989), 501.

6) Y. Ueshima, Y. Sawada, S. Mizoguchi and H. Kajioka: Metall. Trans. A, 20A (1989), 1375.

7) H. A. Wriedt and Hsun. Hu: Metall. Trans. A, 7 (1976), 711.

8) E. T. Turkdogan, S. Ignatowicz and J. Pearson: J. Iron Steel Inst., 180 (1955), 349.

9) "Metals Handbook", 8th Ed., ed. by T. Lyman, H. E. Boyer, W. J. Carnes and M. W. Chevalier, Metals Park, OH, (1973), Vol. 8.

10) T. Nakamura and H. Esaka: Tetsu-to-Hagané, 67 (1981), S140.

11) "Tekkou no Gyoko", suppl. ed. by the Solidification Committee of ISIJ, ISIJ, Tokyo, (1977), S32.
12) Iron and Steel Handbook, 3rd Ed., ed. by ISIJ, Maruzen, Tokyo, (1988), 193-194.

13) $Y$. Ueshima, K. Isobe, S. Mizoguchi and H. Kajioka: Tetsu-to-Hagané, 74 (1988), 465.

14) N. Sano: Proc. of the Int. Symp; Second Canada-Japan Symp. on Modern Steelmaking and Casting Techniques, ed. by J. J. Jonas, J. D. Boyd and N. Sano, Toronto, Ontario, Aug. 20-25, (1994), 19-28.

15) J. Hasegawa, K. Morita and N. Sano: Tetsu-to-Hagané, 81 (1995), 1109.

16) "Steelmaking Data Source Book", ed. by the 19th Committee on Steelmaking in the Japan Society for the Promotion of Science, Gordon and Breach, Montreux, (1988), 168.

17) K. Morita, Y. Morioka, F. Tsukihashi and N. Sano: CAMP-ISIJ, 8 (1995), 185. 